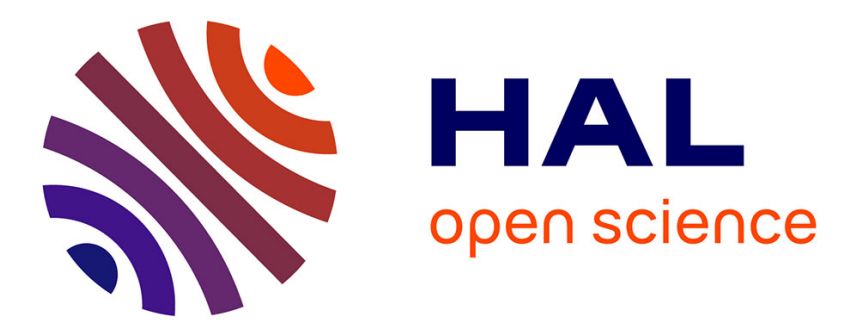

\title{
Dissolved gases in groundwater and groundwater dating methods: How useful for hydrogeological modeling? - Foreword to the special issue
}

\author{
Luc Aquilina, Daren Gooddy, Jean-Raynald De Dreuzy
}

\section{- To cite this version:}

Luc Aquilina, Daren Gooddy, Jean-Raynald De Dreuzy. Dissolved gases in groundwater and groundwater dating methods: How useful for hydrogeological modeling? - Foreword to the special issue. Applied Geochemistry, 2014, 50, pp.115-117. 10.1016/j.apgeochem.2014.07.011 . insu-01097310

HAL Id: insu-01097310

https://hal-insu.archives-ouvertes.fr/insu-01097310

Submitted on 28 Oct 2015

HAL is a multi-disciplinary open access archive for the deposit and dissemination of scientific research documents, whether they are published or not. The documents may come from teaching and research institutions in France or abroad, or from public or private research centers.
L'archive ouverte pluridisciplinaire HAL, est destinée au dépôt et à la diffusion de documents scientifiques de niveau recherche, publiés ou non, émanant des établissements d'enseignement et de recherche français ou étrangers, des laboratoires publics ou privés. 


\section{Dissolved gases in groundwater and groundwater dating methods: how useful for hydrogeological modeling? - Foreword to the special issue}

Luc Aquilina ${ }^{1}$, Daren Gooddy ${ }^{2}$, Jean-Raynald de Dreuzy ${ }^{1}$

and the G-DAT scientific committee: Luc Aquilina (Rennes 1 University - CNRS, F), Florent Barbecot (Paris XI University - CNRS, F), Eurybiades Busenberg (US Geological Survey, USA), Peter Cook (Flinders University - CSIRO, AU), Daren Gooddy (British Geological Survey, UK), Rolf Kipfer (EAWAG, CH), Ate Visser (Lawrence Livermore National Laboratory, USA)

${ }^{1}$ Université Rennes1 - CNRS, OSUR - Géosciences Rennes, Campus Beaulieu, Av. du Gal. Leclerc, 35000 Rennes, France

${ }^{2}$ British Geological Survey, Maclean Building, Wallingford, Oxfordshire, OX10 8BB, UK

\section{Introduction}

One of the major challenges in hydrogeology is the basic spatial lack of continuous data as this is restricted to available boreholes. Basic information is provided by the measurements of physical parameters (e.g. porosity and permeability) at the well-scale. Information related to a larger part of the aquifer are provided for example, by continuous measurement of piezometric levels or spring flow. Temporal information is extremely powerful in order to characterize aquifer functioning globally. Groundwater dating has thus been developed in order to provide time-constraints in aquifer studies.

For young groundwater $(<50$ yrs $)$ tritium measurements were used following nuclear tests during the 1950s and 1960s. Tritium accumulated in the atmosphere and so provided a useful environmental tracer for water originating from this era. Although several monitoring networks from International Atomic Energy Agency provide precise records, seasonal and spatial variations in the tritium precipitation content limit the precision of groundwater dating using this method. Furthermore, tritium levels have decreased gradually and now precipitation concentrations are close to natural background. Groundwater dating using chlorofluorocarbons (CFCs) and more recently sulfur hexafluoride $\left(\mathrm{SF}_{6}\right)$ were also widely developed during the last decades (Busenberg and Plummer, 1992; Busenberg and Plummer, 2000; Cook et al., 1995). CFC concentrations have been rapidly increasing in the atmosphere during the second half of the $20^{\text {th }}$ century and their input history is well known with limited spatial variations. Compared with other groundwater dating techniques, CFCs can be rapidly determined, they require no sophisticated sampling equipment and analysis is relatively 
simple (Gooddy et al., 2006). Consequently, for more than a decade, a number of laboratories have routinely analyzed groundwaters for these compounds. However, several processes such as contamination, degradation and sorption may modify the CFC concentrations in the soils and aquifers so restricting their use as potential tracers. Furthermore, the prohibition of CFCs by the Montreal protocol (1987) has led to a slow decline of their atmospheric concentrations. This decline increases the uncertainty of their use for modern groundwater. $\mathrm{SF}_{6}$ is not subject to the Montreal protocol and its continued release from industrial processes has led to a rapid increase in atmospheric concentrations. Although it has even lower concentrations than the $\mathrm{CFCs}$, it is now analyzed by several laboratories. The interest in $\mathrm{SF}_{6}$ has been limited by potential rock production (Friedrich et al., 2013). ${ }^{85} \mathrm{Kr}$ has also been used as a potential tracer with similar characteristics to CFC although not prone to their associated problems (Cook and Solomon, 1997; Lehmann et al., 1991). The development of new tracers such as ${ }^{39} \mathrm{Ar},{ }^{81} \mathrm{Kr}$, (Loosli et al., 1999; Edmunds et al., 2014), $\mathrm{SF}_{5} \mathrm{CF}_{3}$ and $\mathrm{CFC}-13$ (Busenberg and Plummer, 2008) continues. In recent years and following on from tritium measurements, the tritiumhelium $\left({ }^{3} \mathrm{H} /{ }^{3} \mathrm{He}\right)$ method has also been used (Solomon et al., 1993). It is based on the measurement of the ${ }^{3} \mathrm{He}$ produced from the radioactive decay of tritium contained in groundwater. Although it is often preferred to CFCs by hydrogeologist, it implies the precise determination of the atmospheric, terrigenic and mantle-derived helium contributions which might be challenging (Poreda et al., 1988; Schlosser et al., 1988).

Groundwater dating has been used in various type of sub-surface environment, although heterogeneous aquifers such as karstic or fractured aquifers have been less intensively investigated (Ayraud et al., 2008). In young groundwater systems, a combination of groundwater dating techniques has been helpful to investigate important environmental issues such as sources, fate and transport of contaminants, and groundwater surface water interactions for resource management.

"Old" groundwaters can be more problematic (Philips and Castro, 2003). First, there are fewer tools that have the capability to date these groundwater and each tracer has a relatively narrow residence-time range. Second, deep and ancient fluids represent highly complex mixtures including water transported by advection and solutes provided from the rock matrix through dissolution and diffusion processes (Aquilina et al., 2011). In addition very old groundwater may also mix with various amounts of modern groundwater, sometimes through the process of sampling, leading to wide ranges of groundwater residence-times in a single sample (Corcho Alvarado et al., 2007). Carbon-14 has been used for decades but water-rock 
interactions with carbonate rocks can make it difficult to interpret. Chlorine-36, radiogenic helium and ${ }^{81} \mathrm{Kr}$ have also been used to investigate groundwater in the range of $10^{3}$ to $10^{6}$ years (Marine, 1979) although the use of an appropriate technique often requires an a priori knowledge of the groundwater age.

Beside groundwater dating advancements, the integration of groundwater "ages" in hydrogeological modeling has been developing in parallel. Modeling has prompted some questioning as to the meaning of groundwater dating. Although the concept of "age" appears straightforward and very meaningful to end users, it requires assumptions about hydrogeological functioning. Indeed, the "age" determined from the atmospheric concentration deduced from the groundwater concentration represents a "piston-flow" residence-time. Piston flow is however a highly unlikely model of aquifer functioning. The use of lumped models in order to interpret tracer concentrations has become widely used (Clark and Fritz, 1997). This is a first raw interpretation of tracer concentrations and provides a framework to establish a groundwater flow model. However, mixing at various scales may require much more complex models (Leray et al., 2013). There is still research needed to analyze the relationships between the distribution of tracers in aquifers and the hydrogeological parameters.

As groundwater dating remains an important issue for hydrogeological sciences, two recent workshops have been devoted to groundwater dating (Osenbrück et al., 2010). The second of these was organized in Rennes, western France (October 15-17, 2012). Before the G-DAT meeting, an inter-laboratory comparison exercise was organized. Dissolved gases analyses represent technical difficulties as they require extremely low analytical thresholds. Detailed sampling protocols have been published (IAEA, 2006, 2011; Busenberg and Plummer, 1992, 2000). The International Atomic Energy Agency (IAEA) regularly organizes inter-laboratory comparison of the analytical technics ("TRIC", Gröning et al., 2009). However, different laboratories use various methods for sampling which may induce significant uncertainties between analyses. The aim of the 2012 G-DAT inter-comparison exercise was thus to compare the sampling and analytical protocols from various laboratories.

The inter-comparison exercise was designed by a scientific committee. The idea was to first use a rather simple and homogeneous aquifer and secondly a more complex and heterogeneous one. The first sampling exercise (February 2012) took place in the Fontainebleau Miocene sand aquifer and Dogger limestone deep aquifer. Directly following the G-DAT meeting (October 2012) the second sampling exercise was carried out in a 
fractured aquifer (Ayraud et al., 2006). In both cases, a surface shallow aquifer and a deeper aquifer were sampled. Special attention was given to ensure the homogeneity of the groundwater sampled by all of the teams.

The G-DAT meeting was an opportunity to present the results of the inter-comparison exercise on one side and to bring together geochemists and modelers. This special issue "Dissolved gases in groundwater and groundwater dating methods: how useful for hydrogeological modeling?" reflects this meeting between geochemists and modelers as there are three subsections in the special issue. The first section is devoted to the inter-comparison exercise. It includes both the results of the noble gas and tritium inter-comparison (Visser et al., this issue) and those of the $\mathrm{CFC}_{\text {and }} \mathrm{SF}_{6}$ inter-comparison (Labasque et al., this issue). A paper presenting the inter-comparison design and the site choice which have been the subject of discussions has been presented previously (Labasque et al., 2014). The second section is devoted to contemporary application of groundwater dating methods. It includes multi tracer studies in Austria (Kralik et al., 2014) and Italy (Mayer et al., 2014), and papers investigating pesticide transport (Akesson et al., 2014), helium fluxes (Mahara et al., 2014) as well as karstic systems (Delbart et al., 2014). The third section is devoted to the integration of groundwater dating data in hydrogeologic models in order to investigate the physical meaning of residence time/age concepts. It includes a paper advocating that the term "groundwater age" is misleading (Suckow, 2014), two papers illustrating the use of Bayesian modeling (Massoudieh et al., 2014a,b) and two papers devoted to ${ }^{36} \mathrm{Cl}$ use in paleoclimate studies (Petersen et al., 2014; Rebeix et al., 2014).

\section{Acknowledgements}

The G-DAT meeting and the inter-comparison exercise beneficiated from the efforts of all the teams that participated in the exercises, although the conditions were not always ideal. We want to thank all the participants for their help and their enthusiasm. G-DAT also benefitted from the financial support of International Atomic Energy Agency, Université Rennes 1, CNRS, Observatoire des Sciences de l'Univers de Rennes (OSUR) Geosciences Rennes laboratory, the National Hydrogeological network $\mathrm{H}+$, the Ministère de l'Enseignement Supérieur et de la Recherche, the Région Bretagne, the Syndicat Mixte de Production d'eau Potable du Bassin Rennais (SMPBR) and Véolia Group. Many people at Université Rennes 1 helped with the meeting and field organization. Although it is not possible to mention them all, they are all gratefully thanked.

\section{References}


Akesson, M., Bendz, D., Carlsson, C., Sparrenbom, C., Kreuger, J., 2014. Modelling pesticide transport in a shallow groundwater catchment using tritium and helium-3 data. Applied Geochem., this issue.

Aquilina, L., De Dreuzy, J.R., 2011. Relation of present saline fluid with paleomigration of basinal brines at the basement/sediment interface (Southeast basin - France). Appl. Geochem., 26-12, 1933-1945.

Ayraud, V., Aquilina, L., Pauwels, H., Labasque, T., Pierson-Wickmann, A.-C., Aquilina, A.-M., Gallat, G., 2006. Physical, biogeochemical and isotopic processes related to heterogeneity of a shallow crystalline rock aquifer. Biogeochem., 81-3, 331-347.

Ayraud, V., Aquilina, L., Labasque, T., Pierson-Wickmann, A.C., Molenat, J., Pauwels, H., Fourre, E., Tarits, C., Bour, O., Durand, V., Le Corre, P., Merot, P., Davy, P., 2008. Compartmentalization of physical and chemical properties in hard-rock aquifers deduced from chemical and groundwater age analyses. Appl. Geochem., 23-9, 2686-2707.

Busenberg, E., Plummer, L.N., 1992. Use of chlorofluorocarbons $\left(\mathrm{CCl}_{3} \mathrm{~F}\right.$ and $\left.\mathrm{CCl}_{2} \mathrm{~F}_{2}\right)$ as hydrologic tracers and age-dating tools: Example - The alluvium and terrace system of central Oklahoma. Water Resour. Res., 28-9, 2257-2284.

Busenberg, E., Plummer, L.N., 2000. Dating young groundwater with sulfur hexafluoride: Natural and anthropogenic sources of sulfur hexafluoride. Water Resour. Res., 36, 3011-3030.

Busenberg, E., Plummer, L.N., 2008. Dating groundwater with trifluoromethyl sulfurpentafluoride $\left(\mathrm{SF}_{5} \mathrm{CF}_{3}\right.$, sulfur hexafluoride $\left(\mathrm{SF}_{6}\right), \mathrm{CF}_{3} \mathrm{Cl}(\mathrm{CFC}-13)$ and $\mathrm{CF}_{2} \mathrm{Cl}_{2}(\mathrm{CFC}-12)$. Water Resour. Res. 44, 2, W02431.

Clark, I.D., Fritz, P., 1997. Environmental Isotopes in Hydrology. Boca Raton, FL: Lewis. 328pp.

Cook, P.G., Solomon, D.K., Sanford, W.E., Busenberg, E., Plummer, L.N., Poreda, R.J., 1996. Inferring shallow groundwater flow in saprolite and fractured rock using environmental tracers. Water Resour. Res., 32, 1501-1509.

Cook, P., Solomon, D.K., Plummer, L.N., Busenberg, E., Schiff, S.L. 1995. Chlorofluorocarbons as tracers of groundwater transport in a shallow silty sand aquifer. Water Resour. Res., 31, 425434.

Cook, P.G., Solomon, D.K., 1997. Recent advances in dating young groundwater: Chlorofluorocarbons, ${ }^{3} \mathrm{H} /{ }^{3} \mathrm{He}$ and ${ }^{85} \mathrm{Kr}$. J. Hydrol., 191, 245-265.

Corcho Alvarado, J. A., Purtschert, R., Barbecot, F., Chabault, C., Rueedi, J., Schneider, W., Aeschbach-Hertig, V., Kipfer, R., Loosli, H.H. 2007. Constraining the age distribution of highly mixed groundwater using ${ }^{39} \mathrm{Ar}$ : A multiple environmental tracer $\left({ }^{3} \mathrm{H} /{ }^{3} \mathrm{He},{ }^{85} \mathrm{Kr},{ }^{39} \mathrm{Ar}\right.$ and $\left.{ }^{14} \mathrm{C}\right)$ 
study in the semi confined Fontainebleau Sands Aquifer (France), Water Resour. Res., 43, W03427.

Delbart, C., Barbecot, F., Valdes, D., Tognelli, A., Fourre, E., Purtschert, R., Couchoux, L., JeanBaptiste, P., 2014. Investigation of young water components in karst aquifer systems using $\mathrm{SF}_{6}{ }^{-}$ CFC- ${ }^{3} \mathrm{H} /{ }^{3} \mathrm{He}_{-}{ }^{85} \mathrm{Kr}-{ }^{39} \mathrm{Ar}$ and stable isotope components. Applied Geochem., this issue.

Edmunds, M., Darling, G., Purtschert, R., Corcho-Alvarado, J., 2014. Noble gas, CFC and other geochemical evidence for the age and origin of the Bath Thermal Waters, UK. Applied Geochem., 40, 155-163.

Friedrich, R., Vero, G., von Rohden, C., Lessmann, B., Kipfer, R., Aeschbach-Hertig, W., 2013. Factors controlling terrigenic $\mathrm{SF}_{6}$ in young groundwater of the Odenwald region (Germany). Appl. Geochem., 33, 318-329.

Gooddy, D.C., Darling, W.G., Abesser, C., Lapworth, D.J., 2006. Using chlorofluorocarbons (CFCs) and sulphur hexafluoride $\left(\mathrm{SF}_{6}\right)$ to characterise groundwater movement and residence time in a lowland Chalk catchment. J. Hydrol., 330, 44-52.

Gröning, M., Tatzber, H., Trinkl, A., Klaus, P., Duren, M.V., 2009. Eigth IAEA Interlaboratory Comparison on the Determination of Low-Level Tritium Activities in Water (TRIC2008), International Atomic Energy Agency, Vienna.

International Atomic Energy Agency, 2006. Use of chlorofluorocarbons in hydrology : a guidebook. IAEA, Vienna.

International Atomic Energy Agency, 2011. Dating old groundwater: a guidebook. IAEA, Vienna.

Kralik, M., Humer F., Fank J., Harum T., Klammler G., Gooddy D., Sültenfuß J., Gerber C., Purtschert R., 2014. Using ${ }^{18} \mathrm{O} /{ }^{2} \mathrm{H},{ }^{3} \mathrm{H} /{ }^{3} \mathrm{He},{ }^{85} \mathrm{Kr}$ and $\mathrm{CFCs}$ to determine mean residence times and water origin in the Grazer and Leibnitzer Feld groundwater bodies (Austria). Applied Geochem., this issue.

Labasque, T., Aquilina, L., Vergnaud, V., Barbecot, F., 2014. Inter-laboratory comparison of the determination of sulfur hexafluoride $\left(\mathrm{SF}_{6}\right)$ and three chlorofluorocarbons (CFC-11, -12 and 113 ) in groundwater and air standard. Appl. Geochem., this issue.

Labasque, T., Aquilina, L., Vergnaud, V., Hochreutener, R., Barbecot, F., Casile, G., 2014. Intercomparison exercises on dissolved gases for groundwater dating - (1) Goals of the exercise and site choice, validation of the sampling strategy. Appl. Geochemistry, 40, 119-125.

Lehmann, B.E., Loosli, H.H., Rauber, D., Thonnard, N., Willis, R.D., $1991 .{ }^{81} \mathrm{Kr}$ and ${ }^{85} \mathrm{Kr}$ in groundwater, Milk River aquifer, Alberta, Canada. Appl. Geochem., 6, 419-423. 
Leray, S., De Dreuzy, J.R., Aquilina, L., Vergnaud-Ayraud, V., Labasque, T., Bour, O., Le Borgne, T., 2014. Temporal evolution of age data under transient pumping conditions. J. Hydrol. (in press).

Loosli, H.H., Lehmann, B. E., Smethie, W. M., 1999. Noble gas radioisotopes: ${ }^{37} \mathrm{Ar},{ }^{85} \mathrm{Kr}$, ${ }^{39} \mathrm{Ar},{ }^{81} \mathrm{Kr}$, in Environmental Tracers in Subsurface Hydrology, edited by P. G. Cook, and A. L. Herczeg, pp. 379-396, Springer, New York.

Mahara, Y., Ohta, T., Morikawa, N., Nakano, T., Tokumasu, M., Hukutani, S., Tokunaga, T., Igarashi, T., 2014. Effects of terrigenic He components on tritium-helium dating: A case study of shallow groundwater in the Saijo Basin. Applied Geochem., this issue.

Marine, I.W., 1979. The use of naturally occurring helium to estimate groundwater velocities for studies of geologic storage of radioactive waste. Water Resour. Res., 15-5, 1130-1136.

Massoudieh, A., Visser, A., Sharifi, S., Broers, H.P., 2014a. A Bayesian modeling approach for estimation of a shape-free groundwater age distribution using multiple tracers. Applied Geochem., this issue.

Massoudieh, A., Leray, S., De Dreuzy, J.R., 2014b. Assessment of the value of groundwater age timeseries for characterizing complex steady-state flow systems using a Bayesian approach. Applied Geochem., this issue.

Mayer, A., Sueltenfuss, J., Travi, Y., Rebeix, R., Purtschert, R., Claude C., Le Gal La Salle, C., Miche, C., Conchetto, E., 2014. A multi-tracer study of groundwater origin and transit-time in the aquifers of the Venice region (Italy). Applied Geochem., this issue.

Osenbrück, K., Weise, S.M., Newman, B.D., 2010. Selected papers from the international workshop G-DAT 2008: groundwater dating using environmental tracers. Isot. Environ. Health Studies, $46,257-258$.

Petersen, J., Deschamps, P., Gonçalvez, J., Hamelin, B., Michelot, J.L., Guendouz, A., Zouari, K., 2014. Quantifying paleorecharge in the Continental Intercalaire (CI) aquifer by a Monte-Carlo inversion approach of ${ }^{36} \mathrm{Cl} / \mathrm{Cl}$ data. Applied Geochem., this issue.

Poreda, R.J., Cerling, T.E., Salomon, D.K., 1988. Tritium and Helium-Isotopes as Hydrologic Tracers in a Shallow Unconfined Aquifer. J. Hydrol., 103, 1-9.

Phillips, F.M., Castro, M.C., 2003. Groundwater dating and residence-time measurements, pp. 451497. In Surface and Ground Water, Weathering, and Soils (ed. J.I.Drever) Vol.5 Treatise on Geochemistry (eds. H.D.Holland and K.K.Turekian), Elsevier, Oxford.

Rebeix, R., Le Gal La Salle, C., Mayer, A., Finkel, R., Claude C., Sueltenfuss J., Simler, R., $2014 .{ }^{36} \mathrm{Cl}$ deposition rate reconstruction from $-12000 \mathrm{BP}$ until present : a study based on groundwater records. Applied Geochem., this issue. 
Schlosser, P., Stute, M., Dorr, H., Sonntag, C., Munnich, K.O., 1988. Tritium He-3 Dating of Shallow Groundwater. Earth Planet. Sci. Lett., 89, 353-362.

Solomon, D.K., Schiff, S.L, Poreda, R.J., Clarke, W.B., 1993. A validation of the 3H/3He method for determining groundwater recharge. Water Resour. Res., 29, 2951-2962.

Suckow, A., 2014. The Age of Groundwater - definitions, models and why we do not need this term. Applied Geochem., this issue.

Visser, A., Fourre, E., Barbecot, F., Aquilina, L., Labasque, T., Vergnaud, V., Esser, B.K., 2014. Intercomparison of tritium and noble gases analyses, apparent ${ }^{3} \mathrm{H} /{ }^{3} \mathrm{He}$ ages and other derived Parameters. Appl. Geochem., this issue. 